Article

\title{
Cultural Sustainability in University Students' Flamenco Music Event Attendance: A Neural Networks Approach
}

\author{
Jesús Manuel De Sancha-Navarro ${ }^{1, * \mathbb{D}}$, Juan Lara-Rubio ${ }^{2}{ }^{\mathbb{C}}$, María Dolores Oliver-Alfonso $\left.{ }^{3} \mathbb{(}\right)$ and \\ Luis Palma-Martos ${ }^{4}$ \\ 1 Department of Business Administration and Marketing, Faculty of Economics and Business Sciences, \\ Universidad de Sevilla, Ramon y Cajal 1, 41018 Seville, Spain \\ 2 Department of Finance and Accounting, Faculty of Economics and Business Sciences, Universidad de \\ Granada, Paseo de Cartuja, 7, 18011 Granada, Spain; juanlara@ugr.es \\ 3 Department of Financial Economics and Operations Management, Faculty of Economics and Business \\ Sciences, Universidad de Sevilla, Ramon y Cajal 1, 41018 Seville, Spain; moliver@us.es \\ 4 Department of Economy and Economic History, Faculty of Economics and Business Sciences, \\ Universidad de Sevilla, Ramon y Cajal 1, 41018 Seville, Spain; lpalma@us.es \\ * Correspondence: jsancha@us.es
}

check for

updates

Citation: De Sancha-Navarro, J.M.; Lara-Rubio, J.; Oliver-Alfonso, M.D.; Palma-Martos, L. Cultural Sustainability in University Students' Flamenco Music Event Attendance: A Neural Networks Approach. Sustainability 2021, 13, 2911. https://doi.org/10.3390/su13052911

Academic Editors: Blanca

Alejandra Camargo and Javier Sánchez García

Received: 27 January 2021

Accepted: 1 March 2021

Published: 8 March 2021

Publisher's Note: MDPI stays neutral with regard to jurisdictional claims in published maps and institutional affiliations.

Copyright: (c) 2021 by the authors. Licensee MDPI, Basel, Switzerland. This article is an open access article distributed under the terms and conditions of the Creative Commons Attribution (CC BY) license (https:/ / creativecommons.org/licenses/by/ $4.0 /)$.

\begin{abstract}
University students consume live music; however, almost 40\% declare that they have never attended a flamenco show, an intangible heritage of humankind. Numerous studies have shown that cultural capital and socioeconomic profile, among other factors, are variables that influence cultural consumption, and therefore, cultural sustainability. Considering the relationship between several variables, this paper pursues a double objective. On the one hand, identifying the factors that influence attendance at flamenco shows, and on the other, proposing a predictive model that quantifies the likelihood of an individual attending a flamenco show. To this end, we analyse flamenco consumption by means of a survey conducted on 452 university students, using Multilayer Perceptrom (a non-parametric model), a methodology based on an artificial neural network. Our results confirm the importance of cultural capital, as well as personal and external factors, among other. The findings of this research work are of potential interest for management and planning of cultural events, as well as to promote cultural sustainability.
\end{abstract}

Keywords: culture; sustainability; attendance; flamenco music; event; consumption

\section{Introduction}

Flamenco is a music style that according to the Royal Spanish Academy (RAE) can be defined as some social-cultural expressions generally associated to the gypsy people, which are especially popular in Andalusia. UNESCO declared this cultural expression intangible cultural heritage of humanity in Nairobi (Kenya) on 16 November 2010.

Flamenco, understood as a series of cultural expressions, plays a very relevant role in Spain's culture, and even further in Andalusia's culture. The Regional Government of Andalusia, in its section on culture, has allocated a specific area to Flamenco, which it considers our most authentic cultural identity: it is the art of our land, a symbol that identifies us as Andalusians within our borders and beyond them.

Focusing on the economy of Flamenco, ref. [1] highlighted the importance of Flamenco for the development of the Andalusian Cultural Industry due to its contribution to improving Spain's image abroad, considering that it is an export product, which increases the richness and importance of the local culture [2]. Indeed, last year more than 6.3 million people attended flamenco venues. Only 300,000 among them where nationals, which explains its high dependence from foreign tourism, as it employees directly 3400 people. Moreover, according to a report of the Regional Ministry of Tourism Flamenco [3], in its song (cante) and dance (baile) versions, Flamenco stands out as one of the top tourist 
attractions in the region of Andalusia and, more specifically, in the city of Seville. Across the region, there has been a substantial increase in the supply of live Flamenco shows in recent years [4]. This is one of the reasons leading us to focus our research on this region.

Cultural consumption plays an important role in the study of consumption, culture and lifestyle [5-8]. Many authors point to at the importance of knowing the determinants of cultural consumption; however, there is a smaller number of papers addressing cultural consumption among the youth. Chaparro et al. [9] conducted a study using surveys and interviews in Colombia that showed that the youth have a special preference for music of all styles, but they prefer folk music to a lesser extent. Terrazas [10] carried out a very interesting research study surveying university students of the University of Chihuahua on their cultural consumption, and it was found that the environment has an impact on the music consumption habits of university students. On the other hand, Hinojosa [11] researched by means of questionnaires the cultural consumption patterns of the university community at the University of Nuevo Leon and concluded that screen-based habits (TV, smartphone, etc.) prevailed over other forms of cultural consumption.

Likewise, ref. [12] analysed the non-monetary impacts of education on leisure time use, and they found that educational level has a major impact on the time devoted to leisure time activities in Spain (non-monetary impacts of education on time use), i.e., they demonstrated a high correlation between educational level and the chance of taking part in each leisure activity. We may therefore think that the higher the educational level, the greater the probability to attend cultural events. For this reason, we decided to conduct our research in university students.

However, except for the study conducted by [13], addressing the importance of educational level in music listening habits, and the work of [14], using a different methodology, no research has been conducted to identify the main explanatory factors for attendance at live flamenco shows. Hence, we have previously tried to identify in the literature those factors that by means of causal relationships affect cultural consumption in a wide range of fields of culture and within the context of various theoretical models.

The traditional approach in participation models links participation to the different accumulation of cultural consumption capital, which in turn, has an impact on the relative efficiency of cultural experiences [15-18]. Aguado and Palma [19], based on a careful review of the theoretical and empirical literature, expand the determining factors of cultural participation to include structural factors that limit it, beyond individual characteristics and accumulated cultural capital. These factors would be connected to institutional and technological aspects conditioning the social and economic appraisal of cultural participation.

Other determining factors of cultural consumption focus on age and gender [19]. Moreover, many studies highlight demographic and socioeconomic variables as significant ones in cultural consumption [20-24]. Likewise, education and family environment are directly connected to cultural consumption [25].

All these determining factors configure the dependent variables of the predictive model we use to achieve the goal of our research, i.e., determination of the probability to attend flamenco shows. This may be relevant in managing or planning a given cultural supply, since it is truly relevant to be able to have pertinent information available on the likelihood or unlikelihood of the target population attending shows. Participation statistics are a measure of how the population consumes (demands) the available cultural goods and services (supply), since "a very relevant aspect of the studies on cultural goods and services demand, and a very useful one in designing a cultural policy, has to do with the difference between simple participation (attendance or no attendance) and frequency of participation (number of attendances)" [26].

Various models have been used to analyse cultural consumption. For example, ref. [27] analysed the demand for live theatre performances using a maximum likelihood demand estimation method by least ordinary squares. Gray [21] presented a study to determine the cultural choice patterns in the consumption of music in Italy, and at the same time 
evaluated the likelihood different music styles by means of a logit multinomial model. This method has been also used by [28], who used data from two music festivals in South Africa to explore the determinants of ticket sales. A logistic regression model was used by [29] to identify the determinant factors of likelihood and frequency of attendance at performing arts events in Taiwan; and [22] mentions zero-inflated negative binomial regression as a participation model, which is also used by [4,30]. In turn, ref. [31] researched reading habits and attendance at libraries using two ordered probit methods. These models were also used by [24] to examine the demographic and socioeconomic characteristics that influence the decision to visit museums and archaeological sites. Prieto and Fernández [32] used a two-variable probit method to analyse the differences in the consumption of pop and classic music. More recently, a similar study by [14] analysed the explanatory factors of attendance at flamenco shows by means of a logit model. In conclusion, the two most frequently used models are logit/probit regressions and zero-inflated negative binomial regression models.

However, some authors support other models. Palocsay and White [33] describe the use of neural networks as an alternative method to study the different dimensions of culture and demonstrate their ability to model data relations more precisely than multiple regression analysis. This paper contains a comprehensive discussion of the development and validation of neural networks models as a guide for management researchers interested in exploring this methodology.

According to [34], artificial neural networks (AN) are processing systems inspired in the functioning of the human brain and are capable of processing and interpreting diffuse information, which turns them into adequate techniques to model human perception. It is a mathematical abstraction of how natural brain cells work. According to these authors, whenever a user appraises a consumer good, he/she performs a mental process on which the ANN model is based.

There are research papers on the application of neural networks to the field of music (the purpose of this paper). In most cases, they address models used for music perception with neuroscience application. Bashwiner et al. [35] studied the creative processes that take place at brain cell level in the brain cortex, trying to find out how the regions coordinate with each other, and they underline in their conclusions, for example, the bilateral activity at the cerebellum. On the other hand, the objective of [36] is to help composers to compose music more fluently and to achieve a style that is accepted by a larger audience. To this end, they developed a music creation system for children based on genetic algorithms and neural networks. Their findings show that these algorithms, with the help of computers, allow composers to improve the technology used for composing and, ultimately, to compose music more easily. In another research study, the goal of [37] was to generate pop music melodies with well organised structures; they based their work on a model called PopMNet that uses neural networks and has shown to be more efficient than other models. However, we must also underline the application of neural networks models to music consumption, the specific purpose of this paper. Thus, ref. [38] presented an approach to model users through recurrent neural networks, by sequential processing of consumed music files, so that they can obtain the music preferences of users over time. This model allows for predicting the future songs the user will likely listen to, in the medium and long term.

Therefore, the implications and findings of previous empirical research support the opportunity and interest of this research work, which has a double purpose. First, we want to identify the factors influencing attendance at flamenco shows; and second, provide the managers of such shows with a tool to improve their efficacy, efficiency and cost-effectiveness in running the business. In fact, this is an important contribution to promote cultural capital and with that, cultural sustainability [39], as cultural attendance is considered an important indicator of cultural sustainability [40,41], and in terms of social sustainability, it adds social connections in the forms of bonding, sense of community, and belonging [42]. 
In order to achieve the double purpose mentioned before, and using a sample built on questionnaires circulated to 452 students of the University of Seville, we have used neural networks to build our explanatory and predictive model. Many studies have found that neural networks (NN) are a feasible alternative to traditional statistical models for classification and prediction [33]. Multilayer Perceptrom (MLP) is the type of neural network most frequently used in sales studies [43], having moreover a clear influence on culture [44]. According to [45], neural network analysis represents an exciting and complementary computational methodology for intercultural researchers, and they recommend and encourage such researchers to implement it. They consider that, in theory, $\mathrm{NN}$ can bring any continuous no-lineal function to a high level of preciseness because its non-parametric nature effectively removes the need to verify the adequate model form, to carry out all the necessary data transformation and to meet the regression assumptions. It is therefore an optimal way to predict the behaviour of subjects, and in this research work, we have applied the advantages of this on parametric methodology to predict attendance at flamenco shows.

The main finding of this research paper is the identification of personal, human capital, cultural and external factors that explain and predict attendance at flamenco shows.

\section{Theoretical Framework}

Since the seminal paper of [46], the explanation of the "participation gap" identified by the authors in performing arts, but applicable to other cultural activities too, has led to the development of a large theoretical and empirical body of literature. The "participation gap" means that cultural participation is concentrated in a small section of the total population: urban population with high education and income levels. Therefore, from the cultural economics perspective, such a gap has been explained as the result of individual and home environmental features concerning the inter-generational transfer of cultural consumption skills.

Going into further detail, as we have previously seen, classic participation models are connected to the different accumulation of cultural consumption capital, which affect the relative efficiency of the cultural experience [15-18]. Ferilli and Sacco [47] noted that cultural experiences allow individuals to develop new skills, implying an extension of their consumption product range, where creative and innovative elements are key.

In any case, if we focus on the factors determining cultural consumption, we can see that there are four groups that have been studied by the main authors in the field: personal characteristics, socioeconomic factors, human and cultural capital, and external factors. Table 1 below shows the aspects each of the authors has focused on. Human and cultural capital stands out, since it has been addressed in most research studies on the matter and also represents the starting point for studying cultural sustainability [48,49]. Notwithstanding, there are authors that have studied the other determining factors, as we can see below:

Table 1. Contributions supporting the classification of variables.

\begin{tabular}{cc}
\hline Factors & References \\
\hline Personal characteristics & {$[16,20,24,25,32]$} \\
\hline Socioeconomic factors & {$[20,24,25,32,46,50-52]$} \\
\hline Human and cultural capital & {$[5,12-17,21,22,53,54]$} \\
\hline External factors & {$[5-8,19,23]$} \\
\hline
\end{tabular}

Some of them highlight characteristics such as age, gender, and socioeconomic level. For example, ref. [19] conducted an empirical analysis of "cultural election patterns" concerning music consumption in Italy, trying to verify whether music preferences are diversified, and based on the cultural goods demand model proposed by [16], they found that age, gender, and education are important predictors of an omnivorous cultural taste. In 
turn, ref. [32] analysed the differences between classic music and folk music consumption, and they observed that there is an inborn taste for both styles, which in the case of folk music, decreases with age, except for the 30-45 year old range. Additionally, they found that parents' educational level has a positive impact on listening to classic music bot not to folk music. Falk and Katz-Gerro [24] examined to what extent demographic and socioeconomic characteristics influence cultural consumption decisions by means of probit models with data from 350,000 individuals from EU countries. They concluded that acquired features, such as education and income, have remarkably similar positive effects across the countries included in the sample, whereas the effect of age and gender are weaker and less consistent across countries. Martin et al. [25] used a survey for their study and explored the socio-demographic, school and university, extracurricular, and family factors associated to the attendance by Australian teenagers to live theatre, music, and dance shows. The hierarchical linear multiple regression showed that gender, age and socioeconomic status were the factors influencing attendance most, although it is clear that these factors linked to each of the arts are formed in different ways. In the authors' opinion, these findings are relevant for policy-makers addressing youth leisure and activities and attendance at such events. The different factors considered significant in this process suggest the need for multi-dimensional policies and practices in this area.

Concerning human and cultural capital, ref. [54] tried to make an empirical observation of the relationships of download, purchase, and attendance at concerts in the behaviour of individuals using the 2007 Cultural Habits and Practices Survey of the Ministry of Culture, applying a least square linear regression and a logistic regression. He concluded that the more records individuals exchange, the more records they buy in physical format and the higher their likelihood to attend concerts. Moreover, he found several variables that influence both behaviours, such as educational level, age, socio-professional situation, or life cycle associated to parenthood. The same author, in another paper [55], tried to delimit the cultural consumption patterns, using stratification theories. He found evidences suggesting that cultural consumption still present social stratification characteristics in contemporary Spanish society and that practices considered as "high culture" are associated to the best-positioned strata. Continuing with human and cultural capital, ref. [22] discussed the relevance of human capital in explaining differences in cultural consumption and estimated the impact of the availability of this individual resource on the differences in attendance at cultural activities. For this purpose, he used data of the 2002 United States Survey of Public Participation in the Arts, and he concluded that individuals that have received some type of formal or specific education in arts are more likely to attend a show. In a more recent paper, ref. [56] highlighted the importance of research on cultural participation in Spain, providing a general overview of the main sources of available statistical information on cultural participation, as well as some of the research studies conducted over the two last decades. In conclusion, as [12] believe, as educational level increases, the likelihood to devote time to a wider range of activities significantly increases too, including culture, sports, and reading of journals and books. Likewise, ref. [21] tried, using a logistic regression with data from a 1997 survey, to explore whether early exposure to arts affects participation in adult age and to what extent. He found that lessons enhance participation and control for other influences, although it is not clear whether school is the optimal venue for such lessons, maybe because they tend to by poorly equipped to provide the extension and depth required to achieve effectiveness. Prieto et al. [50] analysed cultural consumption according to taste or price, and again concluded that education is the factor with the greatest impact on cultural consumption, a lack of interest being the main reason for non-attendance, and thus the importance of a good early education.

However, some authors disagree with or question the above conclusions. For example, if we take motivational and demographic factors, ref. [23] set forth that demographic variables are not helpful for managers involved in decision-making on how to develop an audience and fill concert halls. More specifically, concert attendants are not pursuing socialisation opportunities but rather trying to get away. Likewise, authors like [52] 
analysed the factors determining attendance at Chinese opera and surprisingly confirmed that, as far as cultural capital is concerned, that the percentage of population with a university degree or higher has a negative impact on attendance at these types of shows. Regarding the price variable, ref. [51] presented a comparative analysis of the determinants of theatre attendance using a panel dataset on theatres in Austria and Switzerland. Their results suggest that price and income are important, but with elasticity values well below one in absolute terms. Moreover, the findings of price inelastic demand suggest that artistic quality, rather than price cuts, can provide a more effective way of attracting audiences.

On the other hand, one of the features of cultural participation through attendance at live shows is the large number of people that decide not to attend them, something to be taken into account in societies where the supply of cultural goods is not subsidised. It is therefore interesting to find out the factors determining that an individual participates or does not participate [22]. In Spain, there is some research on cultural consumption; the most relevant ones are the National Statistical Plan (2002-2003) and the cultural habits and practices survey organised by the SGAE and the Ministry of Culture, with various editions [5].

\section{Methods}

\subsection{Sample Selection}

The analysis of the work we present is a quantitative approach by means of the survey method. To this end, first we designed a questionnaire, and then we selected the sample according to the data provided by the latest available statistical yearbook (2014-15) of the University of Seville. Taking into account that that total number of students enrolled in the university's own schools was 55.382, according to the widely accepted methods for minimum sample determination [57-59], for a 95.5\% confidence level and a 5\% error margin, the resulting sample need would have to include around 400 individuals.

Then, we calculated the percentage of students in each of the five areas (Health Sciences, Sciences, Engineering and Architecture, Social and Legal Sciences, and Arts and Humanities), as shown in Table 2 in order to obtain the approximate number of surveys to be conducted in each area. At the end, we obtained a larger number of respondents, 452 in total. The selection in each of the areas was fully random.

Table 2. Data for sample selection.

\begin{tabular}{|c|c|c|}
\hline $\begin{array}{c}\text { Porcentage of Students in } \\
\text { Each Area }\end{array}$ & Questionnaires Needed & $\begin{array}{c}\text { Questionnaires Finally } \\
\text { Answered per Programme }\end{array}$ \\
\hline $\begin{array}{l}\text { Health Sciences } \\
8069 \text { students } \\
(14.57 \%)\end{array}$ & 58 & $\begin{array}{l}\text { Odontology (41) } \\
\text { Pharmacy (44) }\end{array}$ \\
\hline $\begin{array}{c}\text { Sciences } \\
3532 \text { students } \\
(6.39 \%)\end{array}$ & 26 & Mathematics (35) \\
\hline $\begin{array}{c}\text { Social and Legal Sciences } \\
21,987 \text { students } \\
(39.7 \%)\end{array}$ & 158 & $\begin{array}{c}\text { Primary Education (44) } \\
\text { Finance-Accounting (53) } \\
\text { Economics (14) } \\
\text { Pedagogy (50) } \\
\text { Business Administration (22) }\end{array}$ \\
\hline $\begin{array}{c}\text { Engineering and Architecture } \\
16,278 \text { students } \\
(29.39 \%)\end{array}$ & 118 & $\begin{array}{l}\text { Engineering (80) } \\
\text { Architecture (20) }\end{array}$ \\
\hline $\begin{array}{l}\text { Arts and Humanities } \\
5516 \text { students } \\
(9.96 \%)\end{array}$ & 40 & Fine Arts (49) \\
\hline $\begin{array}{c}\text { TOTAL } \\
55,382 \text { students }(100 \%)\end{array}$ & 400 & 452 \\
\hline
\end{tabular}




\subsection{Variables}

In order to achieve the main objective of this research, we defined the dependent or explained variable of the model as a dichotomous or dummy variable with a value of 0 for individuals that have not attended a flamenco show and a value of 1 for the opposite case.

Table 3 below summarises the independent variables that will try to explain the process of attending flamenco shows.

Table 3. Explanatory variables.

\begin{tabular}{|c|c|c|}
\hline Code & Acronym & Definition \\
\hline \multicolumn{3}{|r|}{ Personal characteristics } \\
\hline $\mathrm{X} 1$ & Gender & Gender. Dummy variable. $0=$ Female, $1=$ Male \\
\hline $\mathrm{X} 2$ & Age & Age of attendant. Numerical variable. \\
\hline $\mathrm{X} 3$ & Zone & Residence. Dummy variable. $0=$ Andalusia, $1=$ Other. \\
\hline \multicolumn{3}{|r|}{ SOcioeconomic factors } \\
\hline $\mathrm{X} 4$ & M_Stud & $\begin{array}{l}\text { Educational level of mother. Categorical variable. } 0=\text { no formal education, } 1 \text { = basic education, } \\
\qquad 2=\text { intermediate education, } 3=\text { higher education. }\end{array}$ \\
\hline X5 & F_Stud & $\begin{array}{l}\text { Educational level of father. Categorical variable. } 0=\text { no formal education, } 1=\text { basic education, } \\
\qquad 2=\text { intermediate education, } 3=\text { higher education. }\end{array}$ \\
\hline X6 & Income & Monthly income. Categorical variable. $0=€ 0-50,1=€ 51-100,2=€ 101-200,3=+€ 200$ \\
\hline \multicolumn{3}{|r|}{ Human and cultural capital } \\
\hline $\mathrm{X} 7$ & Flam_cult & Flamenco understood as culture. Dummy variable. $0=$ Yes, $1=$ No. \\
\hline $\mathrm{X} 8$ & Flam_art & Flamenco understood as art. Dummy variable. $0=$ Yes, $1=$ No. \\
\hline X9 & Flam_music & Flamenco understood as dance music. Dummy variable. $0=$ Yes, $1=$ No. \\
\hline $\mathrm{X} 10$ & Flam_waylife & Flamenco understood as a way of life. Dummy variable. $0=$ Yes, $1=$ No. \\
\hline X11 & Flam_business & Flamenco understood as a synonym of Andalusia. Dummy variable. $0=$ Yes, $1=$ No. \\
\hline $\mathrm{X} 12$ & Flam_andal & Flamenco understood as a business. Dummy variable. $0=$ Yes, $1=$ No. \\
\hline $\mathrm{X} 13$ & Flam_know & $\begin{array}{c}\text { Level of knowledge of Flamenco. Categorical variable. } 0=\text { none, } 1=\text { poor, } 2=\text { average, } 3=\text { good, } \\
4=\text { very good. }\end{array}$ \\
\hline X14 & Flam_interes & $\begin{array}{l}\text { Level of personal interest. Categorical variable. } 0=\text { none, } 1=\text { poor, } 2=\text { average, } 3=\text { good, } \\
\qquad 4=\text { very good. }\end{array}$ \\
\hline X15 & Previous & Attended shows as a child. Dummy variable. $0=$ Yes, $1=$ No. \\
\hline $\mathrm{X} 16$ & Flam_contact & $\begin{array}{l}\text { Contact though family. Categorical variable. } 0=\text { none, } 1=\text { poor, } 2=\text { average, } 3=\text { good, } \\
\qquad 4=\text { very good. }\end{array}$ \\
\hline X17 & Flam_clothes & Buys flamenco clothes. Dummy variable. $0=$ Yes, $1=$ No. \\
\hline \multicolumn{3}{|r|}{ External factors } \\
\hline X18 & Flam_humanity & Knows that Flamenco is a world heritage treasure. Dummy variable. $0=$ Yes, $1=$ No. \\
\hline X19 & Flam_read & Has read about Flamenco. Dummy variable. $0=$ Yes, $1=$ No. \\
\hline $\mathrm{X} 20$ & Others & Attends other music shows. Dummy variable. $0=$ Yes, $1=$ No. \\
\hline $\mathrm{X} 21$ & Flam_listen & Listens regularly to Flamenco music. Dummy variable. $0=$ Yes, $1=$ No. \\
\hline $\mathrm{X} 22$ & Flam_contribution & $\begin{array}{c}\text { Contribution of Flamenco to culture. Categorical variable. } 0=\text { none or little, } 1=\text { average, } 2=\text { large } \\
\text { or very large. }\end{array}$ \\
\hline
\end{tabular}

\subsection{Artificial Neural Networks Model}

Artificial Neural Networks (ANN) imitate the neural activity in the human brain by means of the transformation of inputs into desired outputs using highly interconnected networks of relatively simple processing elements, usually called neurons or nodes. Numerous empirical research works support a particular architecture, the multilayer perceptron (MLP), the universal approximating property being an example of it [60]. Moreover, MLP is the type of neural network most widely used in sales studies [43]. According to Figure 1, MLP usually includes at least three different layers, an input layer, one or more hidden layers, and an output layer [61]. The number of nodes in the input layer corresponds to the number of independent variables, and the number of nodes in the output layer to the number of dependent variables. However, it is more problematic to define the number the number of hidden layers and the number of nodes in those hidden layers. Concerning 
the number of hidden layers, the universal approximating property of MLP established that a hidden layer network is sufficient to model any complex level at any desired level of preciseness [43]; therefore, all our MLPs will have just one hidden layer. As for the number of hidden nodes, according to [62], there is no general rule to determine the optimal number although it is a crucial parameter for optimal performance of the network. The most common way of determining the size of the hidden layer is by means of experiments or trial and error. Following the previous results, we have considered a three-layer perceptron where the output layer is formed by a node that provides an estimate of likelihood of attending flamenco shows.

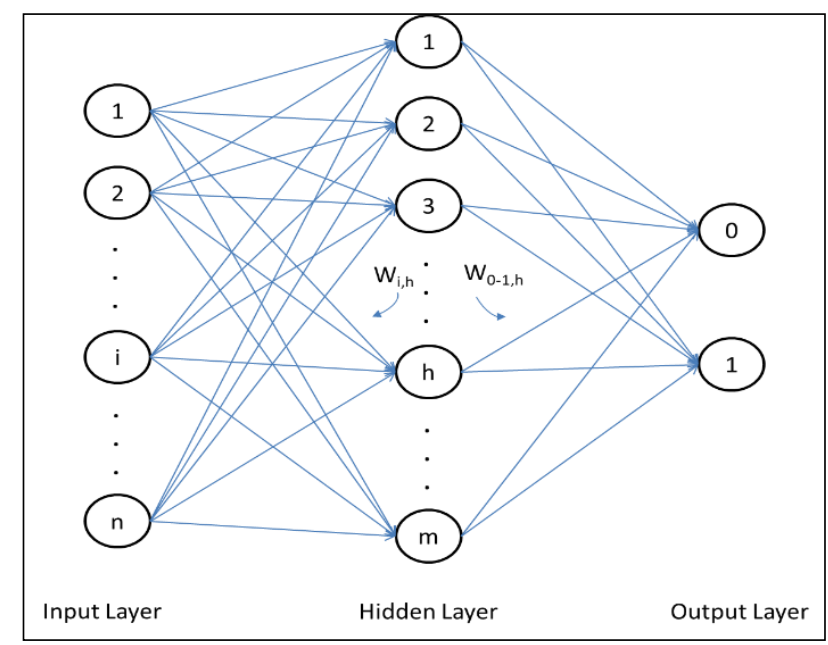

Figure 1. Three-layer multilayer perceptron.

Mathematically, the operation process of a MLP can be represented as follows: Since $\mathrm{H}$ indicates the size of the hidden layer, $\left\{v_{i h}, i=0,1,2, \ldots, p, h=1,2, \ldots, H\right\}$ as the synaptic weight of the connection between the input of size $\mathrm{p}$ and the hidden layer, and $\left\{w_{i h}, h=1,2, \ldots, H\right\}$ as the synaptic weights of the connections between the hidden nodes and the output node, then the output of the neural network from an input vector $\left(x_{1}, \ldots\right.$, $\left.x_{p}\right)$ is:

$$
\hat{y}=g\left(w_{0}+\sum_{h=1}^{H} w_{h} g\left(v_{0 h}+\sum_{h=1}^{H} v_{i h} \cdot x_{j}\right)\right)
$$

Two different programmes are used in the construction of the models of likelihood of attending flamenco shows. The first option is the R system, which is available at no cost. The nnet $\mathrm{R}$ function [63] is adjusted to single-layer neural networks by means of the BFGS (Broyden-Fletcher-Goldfarb-Shanno (BFGS) algorithm can be found in [60]) training algorithm in an effort to minimise the error allowing for a $\lambda$ decay term to prevent overadjustment problems. For classification problems, an appropriate error function is the conditional maximum verisimilitude (or entropy) criterion [64]. Defining $W=\left(W_{1}, \ldots\right.$, $\left.W_{M}\right)$ as the vector of all $\mathrm{M}$ coefficients of the network, and given $\mathrm{n}$ objectives $y_{1}, \ldots, y_{n}$, where $y_{i}=1$ for attendants to flamenco shows, and $y_{i}=0$ in the opposite case, the BFGS is applied to the following problem:

$$
\underset{W}{\operatorname{Min}} \sum_{i=1}^{n}\left(y_{i} \ln \hat{y}_{i}+\left(1-y_{i}\right) \ln \left(1-\hat{y}_{i}\right)\right)+\lambda\left(\sum_{i=1}^{M} W_{i}^{2}\right)
$$

The R implementation of a MLP model requires the specification of two parameters: size of the hidden layer $(H)$ and decay parameter $(\lambda)$; and therefore, a 10-fold crossvalidated search of the size of the hidden layer $(H)$ and the decay parameter $(\lambda)$ is carried out over a grid defined as $\{1,2, \ldots, 20\} \times\{0,0.01,0.05,0.1,0.2, \ldots, 1.5\}$. In this case we have also considered training without regularisation, where $\lambda=0$. 
Neural Network Toolbox [65] with MATLAB R2016b is the other tool used to build a MLP. This commercial system provides a wide range of learning rules and we have considered the four following main training algorithms to train the MLP: gradient descent, quasi-Newton BFGS (similar to R), Levenberg-Marquardt, and enhanced conjugate gradient. These learning rules attempt to minimise the sum of squared errors (SSE):

$$
\operatorname{Min}_{W} \sum_{i=1}^{n}\left(y_{i}-\hat{y}_{i}\right)^{2}
$$

As in $\mathrm{R}$, we face the problem of selecting $\mathrm{H}$; and therefore, the size of the hidden layer $(\mathrm{H})$ is chosen through a 10 -fold cross-validation search in $\{1,2, \ldots, 20\}$ for each learning method.

We chose the use of a MLP type neural network for several reasons: (a) previous research studies have used it as a complement to and a progress over parametric methods, evidencing in most cases a better performance and a higher predictive power, too; (b) MLP neural networks take into account non-linear relations that are not considered in classic parametric methods [66-68].

\section{Analysis of Results}

\subsection{Model Estimations}

Based on [69], we reserved a random sample of $20 \%$ to carry out the validation and performance of the models built.

As opposed to classic parametric methods, the MLP neural network identifies influence on all variables. However, according to the results concerning the weights of each variable obtained with MLP, which are shown in Figure 2, based on the normalized importance of the variables, we have found that there is a higher relative weighing for variables such as previous attendance at flamenco shows during childhood, age of subject, perception of flamenco a dance music, level of contact though family, level of personal interest, and perception of contribution of flamenco to culture. These variables have the highest explanatory power for attendance at flamenco shows. The remaining variables have a normalized relative importance of less than $25 \%$.

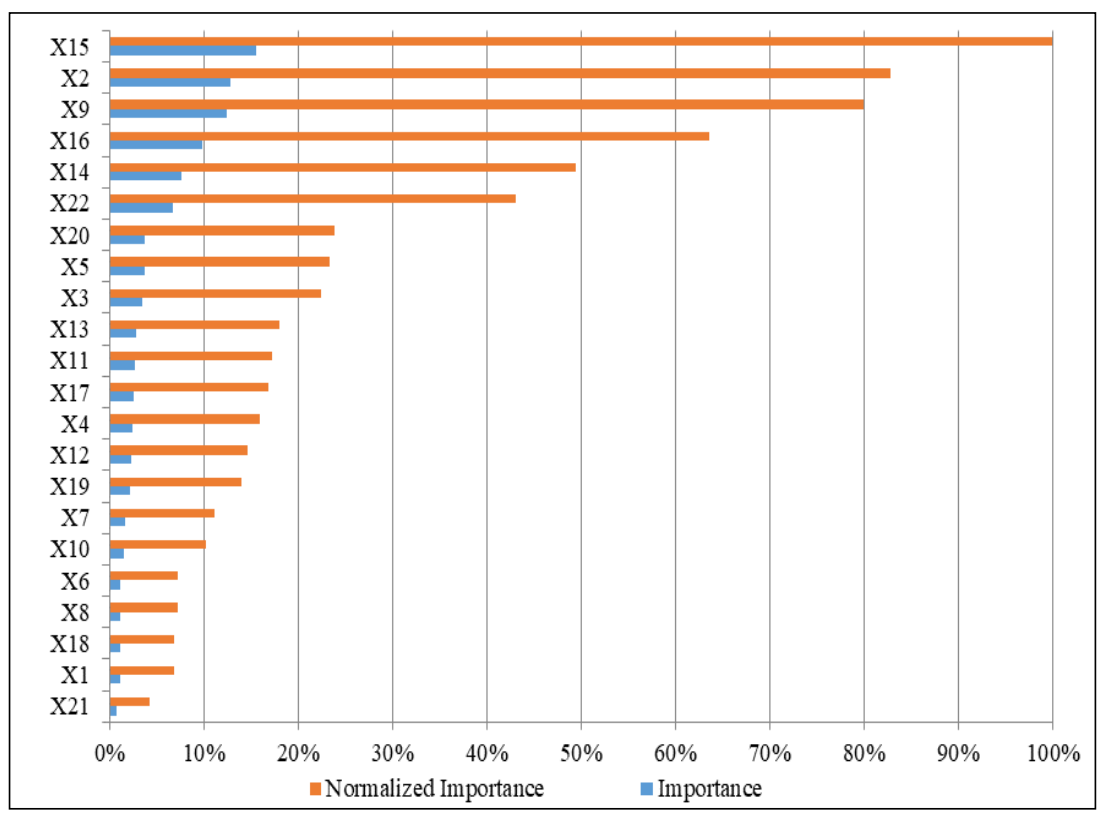

Figure 2. Normalized relative importance.

The classification matrix (Table 4), which compares observed values and predicted values of the dependent variable, measures the correct percentage of the classification, and 
therefore, the predictive power of the model, both for the training sample $(75 \%)$ and for the validation sample (25\%). Likewise, from this matrix we can observe the sensibility and specificity values of the model. We can see in the table a correct classification percentage for $86.6 \%$ of the cases, a figure that is supported by the $84.4 \%$ obtained for the validation sample.

Table 4. Classification Matrix.

\begin{tabular}{ccccc}
\hline \multirow{2}{*}{ Sample } & \multicolumn{3}{c}{ Classification } \\
\hline \multirow{3}{*}{ Training } & Observed & $\mathbf{0}$ & Predicted \\
\cline { 2 - 5 } & 0 & 135 & $\mathbf{1}$ & Percent Correct \\
\cline { 2 - 5 } & 1 & 30 & 17 & $88.8 \%$ \\
\cline { 2 - 5 } & Overall Percent & & 3 & $84.8 \%$ \\
\hline \multirow{2}{*}{ Testing } & 0 & 34 & 41 & $86.6 \%$ \\
\cline { 2 - 5 } & 1 & 11 & & $71.9 \%$ \\
\cline { 2 - 5 } & Overall Percent & & & $78.8 \%$ \\
\hline
\end{tabular}

These predictive values are reasonably acceptable, considering the database we are working with.

Finally, Figure 3 shows the goodness of fit by means of the area under the (ROC) curve, which indicates that the model fits rather well, since the two curves (for 0 and for 1 ) are close to the upper left corner and they separate from the diagonal, which is indicative for the high classification power for the individuals between 0 and 1 .

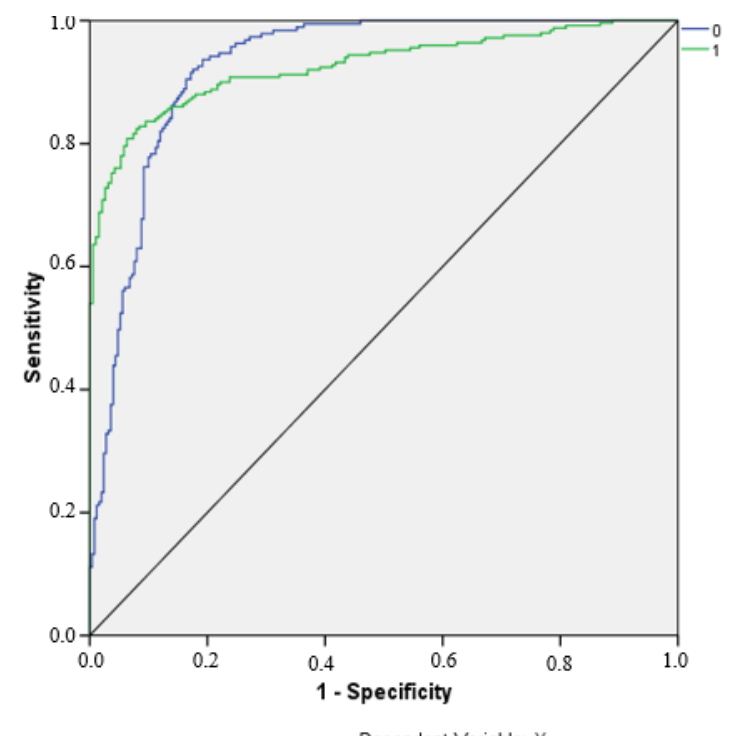

Figure 3. ROC Curve.

\subsection{Discussion}

The results obtained provide an advance on the findings of the previous research, providing new useful knowledge for managers of flamenco shows. In the first place, the methodology used in this work is novel because it provides flamenco shows with a business management tool that improves efficiency and profitability.

Likewise, in the case of the university students surveyed, our results show a degree of explanation of all the explanatory variables used on the probability of attending a flamenco show. Specifically, we found six independent variables with greater explanatory power. 
The results of our proposed model show a relevant importance to the fact that the person surveyed had attended a flamenco show in their childhood. The model also reveals a special sensitivity of the age of the attendee with the probability of attendance, as well as with three factors of human and cultural capital, which answer the questions of whether the person surveyed understands flamenco as dance music, the degree of contact with flamenco through family, and the level of personal interest that people have in the art of flamenco. Finally, regarding external factors, our model also highlights the perception of the contribution of flamenco to culture.

These findings are novel with respect to previous research because we provide specific evidence on the characteristics and profiles of the people who attend flamenco shows and, furthermore, because our results deepen the conclusions of previous studies. Some authors [41-44] have used the non-parametric technique of neural networks in the musical field, but they have not studied what are the explanatory and predictive factors of attendance at flamenco shows.

With our research, we advance on the findings regarding the use of personal characteristics, socioeconomic factors, human and cultural capital, and, finally, external factors. With our findings we propose management tools that allow economic managers to design ad hoc shows for the population of different geographical areas.

\subsection{Limitations and Future Lines of Research}

Despite its contributions, this study is not without limitations, and these limitations provide fruitful avenues for further research.

Firstly, regarding the context within which the research is performed through a personal interview and a questionnaire for the university students, there's a possibility that processed answers would differ depending on the interviewer or other causes such as the moment in time the interview takes place.

With regard to the sample used in this research, despite a previous selection in order to guarantee an adequate level of response respecting the different typologies of the responses themselves, the response rate was relatively low even if slightly higher than in previous similar previous studies. Besides, this study focuses on only one country; it would be necessary to approach multiple countries and encourage comparative cultural studies with the purpose of analyzing the possible resulting cultural differences.

Furthermore, since this study is only an exploratory investigation, no particular flamenco show has been evaluated, but the general intention to attend said flamenco shows. On the other hand, the method used for data collection follows a transversal cut design, which prevents this study from analyzing the evolution of people's behavior over time. A longitudinal design would have allowed testing the strength of developed relationships and constructs as well as checking the evolution of drivers and barriers through time.

Also, both the conclusions drawn from this research and the inherent limitations lay the foundation for future research studies related to the intention to attend a flamenco show.

In this regard, future studies could complete our research incorporating actual data from live flamenco shows and comparing results when this information is not taken into account. This would allow researchers to obtain specific quantitative measures.

Furthermore, with data on the actual use of information from live flamenco shows, a relationship between the intention to attend and the actual attendance could be established and analyzed leading to a discussion of the most significant conclusions. In addition, in order to attain a greater consistency in the results, the research could be repeated in successive years to check for the so-called experience effect, reviewing results and marking changes in variables and relationships.

Lastly, in order to overcome the problems related to a selected sample associated with a national panel survey and with the purpose of generalizing and comparing the results obtained in our research, it would be fruitful to perform the same research in a different 
country or including peoples from different countries (a cross-cultural study) in order to determine the validity and significance of our conclusions. Likewise, along with the cultural expansion of the sample, the temporary update would be interesting, due to the emergence of the COVID19 crisis in our society to consider the changes in behaviors and attitudes of people and individuals.

\section{Conclusions}

Based on an empirical research study on 452 students of the University of Seville, in this paper we have identified personal, human capital, cultural, and external factors that explain and predict attendance at flamenco shows, which we believe affects cultural sustainability. More precisely, previous attendance at flamenco shows during childhood, age of subject, perception of flamenco as a dance music, level of contact through family, level of personal interest, and perception of contribution of flamenco to culture are factors that significantly influence attendance, probably due to a broader vital experience and maturity, in line with the findings of the literature.

Based on our results, we found that human and cultural capital are of great importance. These variables encourage interest for the arts and are capable of building links from an early age through the family, as suggested by previous literature.

We further found that personal perception of the contribution of flamenco to culture is relevant. In this case, it is an external factor related to individuals that value flamenco as an important element of regional culture, and it has a positive impact on attendance at shows, as suggested in the literature discussed in the theoretical framework.

In particular, our findings suggest that music managers should design flamenco shows based on the idiosyncratic variables of potential attendees. Likewise, knowing the explanatory factors for attendance could contribute to increasing income and reducing event expenses. A full domain of all this information could help the manager to identify which artists are more profitable and which attract more publicity or achieved higher levels of consumption.

In summary, we propose a tool that ultimately allows the attendee to be loyal to the event and to ensure that in future occasions, those same attendees are likely to repeat.

Moreover, we studied predictive ability through quantification of likelihood to attend flamenco shows, designing a MLP-type artificial neural network non-parametric model. This methodology is a complement to and a progress over parametric methods, since in most cases it improves performance and takes into account non-linear relations that are not considered in classic parametric methods.

These findings are highly relevant for managers of flamenco shows, since they give them the opportunity to know more effectively the characteristics of their target audience when programming live shows, which effectively allows for and contributes to their feasibility and sustainability. Thus, although the behaviour of attendance at such shows is subject to a high level of uncertainty, cultural managers can forecast with some level of significance whether the success of their cultural project is guaranteed or not in terms of participation.

Moreover, this research work confirms the importance of encouraging the taste for the arts and educating young audiences from an early age, which influences cultural sustainability. To this end, we believe the following is necessary: First, cultural policies should focus on encouraging attendance of parents with their children at a reduced or no price to this type of shows, as well as to stress the music curriculum in formal education, to promote the taste for the arts in school. In this way, as our research suggests, it will be possible to increase attendance at these shows in the future. Second, cultural managers should know the programme, characteristics and cultural impact of an event, and try to match them to their target audience, and they should innovate in practices that make audiences play a more active role.

Finally, we can conclude that inasmuch as cultural businesses continue to be sustainable in the medium and long term, promoting and creating jobs at the same time, greater 
synergies between audiences and artists will be achieved, and ultimately, that culture is sustainable.

Author Contributions: Conceptualization, J.M.D.S.-N. and M.D.O.-A.; methodology, J.L.-R.; software, J.L.-R.; validation, J.L.-R.; formal analysis, J.M.D.S.-N. and M.D.O.-A.; investigation, J.M.D.S.-N. and M.D.O.-A.; resources, J.M.D.S.-N. and J.L.-R.; writing—original draft preparation, J.M.D.S.-N. and J.L.-R.; supervision, M.D.O.-A. and L.P.-M. All authors have read and agreed to the published version of the manuscript.

Funding: This research received no external funding.

Institutional Review Board Statement: Not applicable.

Informed Consent Statement: Not applicable.

Data Availability Statement: The data presented in this study are available on request from the corresponding author.

Acknowledgments: The authors would like to thank the anonymous reviewers who provided many helpful suggestions for improvements.

Conflicts of Interest: The authors declare no conflict of interest.

\section{References}

1. Ortega, C. El Impacto Del Flamenco En Las Industrias Culturales Andaluzas; Universidad Complutense de Madrid: Madrid, Spain, 2006.

2. Negrusa, A.L.; Toader, V.; Rus, R.V.; Cosma, S.A. Study of Perceptions on Cultural Events' Sustainability. Sustainability 2016, 8, 1269. [CrossRef]

3. Turismo Andaluz. La Demanda de Turismo de Flamenco En Andalucía; Junta de Andalucía: Málaga, Spain, 2004.

4. Palma, L.; Palma, M.L.; Rodríguez, A.; Martín, J.L.; Cascajo, I. Live Flamenco in Spain: A Dynamic Analysis of Supply, with Managerial Implications. Int. J. Arts Manag. 2017, 19, 1-14.

5. Ateca-Amestoy, V.; Villarroya, A. Measuring Participation in the Arts in Spain. In Enhancing Participation in the Arts in the EU; Springer: Berlin, Germany, 2017; pp. 19-33. [CrossRef]

6. Katz-Gerro, T. Cultural Consumption Research: Review of Methodology, Theory, and Consequence. Int. Rev. Sociol. 2004, 14, 1-20. [CrossRef]

7. Navarrete, T.; Borowiecki, K.J. Changes in Cultural Consumption: Ethnographic Collections in Wikipedia. Cult. Trends 2016, 25, 233-248. [CrossRef]

8. Zallo, R. La Economía de La Cultura (y de La Comunicación) Como Objeto de Estudio. Zer 2007, 22, 215-234.

9. Chaparro, H.R.; Guzmán, C.M. Jóvenes y Consumo Cultural. Una Aproximación a La Significación de Los Aportes Mediáticos En La Preferencias Juveniles *. Anagramas 2017, 15, 121-142. [CrossRef]

10. Terrazas, F. Estudio Sobre Hábitos de Consumo Cultural y Musical En Estudiantes de La Universidad Autónoma de Chihuahua (México); Universidad de Granada: Granada, Spain, 2014.

11. Hinojosa, L. Consumo y Prácticas Culturales de La Comunidad Universitaria de Una Universidad Mexicana. In III Congrés Internacional Associació Espanyola d'Investigació de la Comunicació; Universitat Rovira i Virgili: Tarragona, Spain, 2012; pp. 1-18.

12. Fernández-Gutiérrez, M.; Calero, J. The Non-Monetary Effects of Education on Leisure: Analysis of the Use of Time in Spain. Estud. Sobre Educ. 2019, 36, 207-229. [CrossRef]

13. Heredia-Carroza, J.; Palma, L.; Marín, A. Determinants of Attendance Frequency to Flamenco Shows. Rev. Metod. Cuantitativos Para la Econ. y la Empres. 2020, 29, 79-98.

14. De Sancha-Navarro, J.M.; Palma, L.; Oliver-Alfonso, M.D. Explanatory Factors of University Student Participation in Flamenco. Econ. Sociol. 2019, 12, 130-148. [CrossRef] [PubMed]

15. Ateca-Amestoy, V. Determining Heterogeneous Behavior for Theater Attendance. J. Cult. Econ. 2008, 32, 127-151. [CrossRef]

16. Levy-Garboua, L.; Montmarquette, C. A Microeconometric Study of Theater Demand. J. Cult. Econ. 1996, 20, 25-50. [CrossRef]

17. Michael, R.; Becker, G.S. On the New Theory of Consumer Behavior. Swed. J. Econ. 1973, 75, 378-396. [CrossRef]

18. Stigler, G.J.; Becker, G.S. De Gustibus Non Est Disputandum. Am. Econ. Rev. 1977, 67, 76-90. [CrossRef]

19. Aguado, L.F.; Palma, L. Factores Que Limitan La Participación Cultural. Una Mirada Desde La Economía de La Cultura. Rev. Cienc. Soc. 2015, 21, 58-71.

20. Favaro, D.; Frateschi, C. A Discrete Choice Model of Consumption of Cultural Goods: The Case of Music. J. Cult. Econ. 2007, 31, 205-234. [CrossRef]

21. Gray, C. Hope for the Future? Early Exposure to the Arts and Adult Visits to Art Museums. J. Cult. Econ. 1998, 22, 87-98. [CrossRef]

22. Ateca-Amestoy, V. El Capital Humano Como Determinante Del Consumo Cultural. Estud. Econ. Apl. 2009, 27, 89-112. 
23. Hager, M.A.; Winkler, M.K. Motivational and Demographic Factors for Performing Arts Attendance across Place and Form. Nonprofit Volunt. Sect. Q. 2012, 41, 474-496. [CrossRef]

24. Falk, M.; Katz-Gerro, T. Cultural Participation in Europe: Can We Identify Common Determinants? J. Cult. Econ. 2016, 40, 127-162. [CrossRef]

25. Martin, A.J.; Anderson, M.; Adams, R.-J. What Determines Young People's Engagement with Performing Arts Events? Leis. Sci. 2012, 34, 314-331. [CrossRef]

26. Aguado, L.F. Estadísticas Culturales: Una Mirada Desde La Economía de La Cultura. Cuad. Adm. 2010, $23,107-141$.

27. Corning, J.; Levy, A. Demand for Live Theater with Market Segmentation and Seasonality. J. Cult. Econ. 2002, 26, 217-235. [CrossRef]

28. Snowball, J. Festival Fringe Production and the Long Tail. Econ. Res. S. Afr. 2016, 576. Available online: https://www.econrsa. org/system/files/publications/working_papers/working_paper_576.pdf (accessed on 25 September 2020).

29. Wen, W.J.; Cheng, T.C. Performing Arts Attendance in Taiwan: Who and How Often? J. Cult. Econ. 2013, 37, 309-325. [CrossRef]

30. Muñiz, C.; Rodríguez, P.; Suárez, M.J. Participation in Cultural Activities: Specification Issues. J. Cult. Econ. 2015, 1-23. [CrossRef]

31. Fernández, V.; Prieto, J. Análisis de Los Hábitos de Lectura Como Una Decisión Económica. Estud. Econ. Apl. 2009, 27, 111-135.

32. Prieto, J.; Fernández, V. Are Popular and Classical Music Listeners the Same People? J. Cult. Econ. 2000, 24, 147-164. [CrossRef]

33. Palocsay, S.W.; White, M.M. Neural Network Modeling in Cross-Cultural Research: A Comparison with Multiple Regression. Organ. Res. Methods 2004, 7, 389-399. [CrossRef]

34. Asensio-Cuesta, S.; Diego-Más, J.A.; Alcaide-Marzal, J.; González-Cruz, M.C. Aplicación de Redes Neuronales Para La Predicción de La Percepción, Por Parte de Los Usuarios, de La Funcionalidad de Un Producto; Asociación Española de Ingeniería de Proyectos (AEIPRO): Badajoz, Spain, 2009.

35. Bashwiner, D.M.; Bacon, D.K.; Wertz, C.J.; Flores, R.A.; Chohan, M.O.; Jung, R.E. Resting State Functional Connectivity Underlying Musical Creativity. Neuroimage 2020, 218, 116940. [CrossRef]

36. Shi, N.; Wang, Y. Symmetry in Computer-Aided Music Composition System with Social Network Analysis and Artificial Neural Network Methods. J. Ambient Intell. Humaniz. Comput. 2020, 1-16. [CrossRef]

37. Wu, J.; Liu, X.; Hu, X.; Zhu, J. PopMNet: Generating Structured Pop Music Melodies Using Neural Networks. Artif. Intell. 2020, 286, 103303. [CrossRef]

38. De Boom, C.; Agrawal, R.; Hansen, S.; Kumar, E.; Yon, R.; Chen, C.W.; Demeester, T.; Dhoedt, B. Large-Scale User Modeling with Recurrent Neural Networks for Music Discovery on Multiple Time Scales. Multimed. Tools Appl. 2018, 77, 15385-15407. [CrossRef]

39. Getzner, M. Spatially Disaggregated Cultural Consumption: Empirical Evidence of Cultural Sustainability from Austria. Sustainability 2020, 12, 10023. [CrossRef]

40. Loach, K.; Rowley, J.; Griffiths, J. Cultural Sustainability as a Strategy for the Survival of Museums and Libraries. Int. J. Cult. Policy 2017, 23, 186-198. [CrossRef]

41. Nijkamp, P.; Riganti, P. Assessing Cultural Heritage Benefits for Urban Sustainable Development. Int. J. Serv. Technol. Manag. 2008, 10, 29-38. [CrossRef]

42. Kinnunen, M.; Homi, H.; Honkanen, A. Social Sustainability in Adolescents' Music Event Attendance. Sustainability 2020, 12, 9419. [CrossRef]

43. Zhang, G.P.; Patuwo, B.E.; Hu, M.Y. Forecasting with Artificial Neural Networks: The State of the Art. Int. J. Forecast. 1998, 14, 35-62. [CrossRef]

44. Zhang, L.; Zhu, J.; Liu, Q. A Meta-Analysis of Mobile Commerce Adoption and the Moderating Effect of Culture. Comput. Hum. Behav. 2012, 28, 1902-1911. [CrossRef]

45. Veiga, J.F.; Lubatkin, M.; Calori, R.; Very, P.; Tung, A. Using Neural Network Analysis to Uncover the Trace Effects of National Culture. J. Int. Bus. Stud. 2000, 31, 223-238. [CrossRef]

46. Baumol, W.J.; Bowen, W.G. Performing Arts: The Economic Dilemma.; Twentieth Century Found: New York, NY, USA, 1966.

47. Ferilli, G.M.; Sacco, P.L. Nuevas Direcciones En Políticas Culturales. Los Distritos Culturales Sistémicos; Editorial Doble J. C.: Seville, Spain, 2012.

48. Throsby, D. Culture, Economics and Sustainability. J. Cult. Econ. 1995, 19, 199-206. [CrossRef]

49. Throsby, D. Cultural, Sustainability. In A Handbook of Cultural Economics; Towse, R., Ed.; Edward Elgar: Cheltenham, UK, 2003; pp. 183-186. ISBN 978-1-84064-338-2.

50. Prieto, J.; Pérez, M.J.; Suárez, S. El Consumo Cultural: ¿Cuestión de Gusto o de Precio? 2018. Available online: https:// observatoriosociallacaixa.org/es/-/el-consumo-cultural_cuestion-de-gusto-o-de-precio (accessed on 25 September 2020).

51. Zieba, M. Determinants of Demand for Theatre Tickets in Austria and Switzerland. Austrian J. Stat. 2011, 40, 209-219. [CrossRef]

52. Wu, J.; Jiang, K.; Yuan, C. Determinants of Demand for Traditional Chinese Opera. Empir. Econ. 2019, 57, 2129-2148. [CrossRef]

53. Scitovsky, T. The Joyless Economy: The Psychology of Human Satisfaction; Oxford University Press: New York, NY, USA, 1976.

54. Herrera-Usagre, M. El Impacto Del Intercambio de Música Sobre La Compra de Discos y La Asistencia a Conciertos. El Caso de España. Papers 2012, 97, 751-772. [CrossRef]

55. Herrera-Usagre, M. El Consumo Cultural En España. Una Aproximación Al Análisis de La Estratificación Social de Los Consumos Culturales y Sus Dificultades Metodológicas. Empiria. Rev. Metodol. Cienc. Soc. 2011, 22, 141-172. [CrossRef]

56. Ateca-Amestoy, V.; Ginsburgh, V.; Mazza, I.; Prieto-Rodríguez, J.; O Hagan, J. Enhancing Participation in the Arts in the EU; Springer: Berlin, Germany, 2017. [CrossRef] 
57. Gujarati, D.N.; Porter, D.C. Econometría; Mc Graw Hill: Mexico D.F., Mexico, 2010.

58. López-Roldán, P.; Fachelli, S. Metodología de La Investigación Social Cuantitativa; Creative Commons: Barcelona, Spain, 2015. [CrossRef]

59. Rositas, J. Los Tamanos de Las Muestras En Encuestas de Las Ciencias Sociales y Su Repercusion En La Generacion Del Conocimiento (Sample Sizes for Social Science Surveys and Impact on Knowledge Generation). Innov. de Neg. 2014, 11, 235-268.

60. Bishop, C.M. Neural Networks for Pattern Recognition; University Press: New York, NY, USA, 1995.

61. Rumelhart, D.E.; Hinton, G.E.; Williams, R.J. Learning Representations by Back-Propagating Errors. Nature 1986, $323,533-536$. [CrossRef]

62. Kim, K.J. Financial time series forecasting using support vector machines. Neurocomputing 2003, 55, 307-319. [CrossRef]

63. Venables, W.N.; Ripley, B.D. Modern Applied Statistics with S; Springer: New York, NY, USA, 2002.

64. Hastie, T.; Tibshirani, R.; Friedman, J.H. The Elements of Statistical Learning: Data Mining, Inference, and Prediction; Springer Series in Statistics: New York, NY, USA, 2009.

65. Demuth, H.; Beale, M. Neural network toolbox for use with Matlab. In User's Guide; The Math Works Inc.: Natick, MA, USA, 1997.

66. Blanco, A.; Pino-Mejías, R.; Lara, J.; Rayo, S. Credit scoring models for the microfinance industry using neural networks: Evidence from Peru. Expert Syst. Appl. 2013, 40, 356-364. [CrossRef]

67. Cubiles-De-La-Vega, M.D.; Blanco-Oliver, A.; Pino-Mejías, R.; Lara-Rubio, J. Improving the management of microfinance institutions by using credit scoring models based on Statistical Learning techniques. Expert Syst. Appl. 2013, 40, 6910-6917. [CrossRef]

68. Liébana-Cabanillas, F.; Lara-Rubio, J. Predictive and explanatory modeling regarding adoption of mobile payment systems. Technol. Forecast. Soc. Chang. 2017, 120, 32-40. [CrossRef]

69. Jones, F.L. Current Techniques in Bankruptcy Prediction. J. Account. Lit. 1987, 6, 131-164. 